\title{
Stella, a New Genus of Soil Prosthecobacteria, with Proposals for Stella humosa sp. nov. and Stella vacuolata sp. nov.
}

\author{
L. V. VASILYEVA \\ Institute of Microbiology, Academy of Science of USSR, Moscow, USSR
}

\begin{abstract}
A new genus, Stella, is proposed for a group of flat, six-pronged star-shaped prosthecobacteria found in freshwater, soil, and sewage in widely separated geographical areas. The morphology of the cells provides clear differentiation from all other eubacteria. The cellular morphology and mode of multiplication of these organisms also provide clear separation from other budding and appendaged prosthecobacteria. The cells are gram negative, flat, nonmotile, and asporogenic. Representative organisms in the genus are chemoorganotrophic, growing on low nutrient concentrations and utilizing a variety of amino acids and organic acids. Two distinct species are recognized. Stella humosa (type species) is an avacuolate organism, and the type strain (strain AUCM B-1137) has been deposited in the All Union Collection of Microorganisms, Moscow, USSR, and in the Institute of Microbiology, Academy of Sciences, Moscow, USSR. Stella vacuolata is a gas vacuolate prosthecobacterium, and the type strain is strain 229 (Institute of Microbiology, Academy of Sciences, Moscow, USSR). Organisms in the genus Stella appear to represent the first example of radial symmetry in procaryotic cells.
\end{abstract}

Flat, star-shaped bacteria were observed first by Nikitin and colleagues (4) in 1966 and shortly thereafter by Staley (6). Since that time, these prosthecobacteria have been discussed in a number of publications $(1,2,7,8 ; \mathrm{H}$. Schlesner, Ph.D. thesis, University of Kiel, Kiel, Federal Republic of Germany, 1983). Pure cultures of one organism were successfully isolated in 1970 (9), and a taxonomic description of this organism as "Stella humosa" was subsequently proposed in 1974 (13). Although the description of this organism and the characteristics of members of the proposed genus were presented in 1981 in a review of various budding and appendaged bacteria $(2,7)$, the genus "Stella" was not included on the Approved Lists of Bacterial Names (5).

At present, there is a collection containing 12 strains of star-shaped prosthecobacteria from different habitats in the Institute of Microbiology of the Academy of Sciences, Moscow, USSR. Several of these strains have been isolated in pure culture. In this paper I provide a formal description of the genus Stella and differentiate two distinct species within this genus.

\section{MATERIALS AND METHODS}

The strains used in this study and their origins are shown in Table 1. The most successful method of recovery of star-shaped bacteria involved the use of enrichment cultures containing prosthecobacteria growing in association with aerobic cellulose-decomposing bacteria on Hutchinson medium (with added filter paper) (12). The initial isolates of the organisms used in this study were obtained on agar plates containing fulvic acids, as previously described (2), or from plates containing a horse manure extract. For the latter plates, dry horse manure was added to distilled water $(1 \mathrm{~g}$ of manure to $100 \mathrm{ml}$ of water), and the mixture was autoclaved at $121^{\circ} \mathrm{C}$ for $20 \mathrm{~min}$. The supernatant was then solidified with $2 \%$ agar (15). Colonies on agar plates were usually mixed, and a long series of subculturing and reisolation of single colonies was required for selection of pure cultures. However, the unique morphology of the star-shaped bacteria is usually obvious under phase-contrast microscopy.

Pure cultures of organisms were maintained in dilute media $(1: 5)$, such as nutrient broth supplemented with beef extract and peptone and solidified with $2 \%$ (wt/vol) agar, or in a medium described by Staley (6), which contains $20 \mathrm{ml}$ of Hutner modified salts solution, $0.25 \mathrm{~g}$ of ammonium sulfate, $0.2 \mathrm{~g}$ of peptone, $0.2 \mathrm{~g}$ of yeast extract, $10 \mathrm{ml}$ of a vitamin solution, and distilled water to a volume of 1 liter.

The guanine-plus-cytosine $(\mathrm{G}+\mathrm{C})$ contents of the deoxyribonucleic acids (DNAs) of the organisms were determined by thermal denaturation (3).

Slide cultures were used to follow the process of cell division with a Reichardt Zetopan microscope equipped with anoptral contrast (Wilke-Reichardt). All other microscopic observations were made with a Zeiss Amplival phasecontrast microscope. Electron microscopy was carried out by using negatively stained specimens (1\% uranyl acetate) and a model JEM $100 \mathrm{C}$ electron microscope.

Utilization of various carbon sources by the organisms was determined in the liquid medium of Staley without peptone and the vitamin solution (6) but supplemented with $0.01 \%$ yeast extract and the selected carbon source at a final concentration of $0.1 \%$ (wt/vol).

\section{RESULTS AND DISCUSSION}

Cell morphology. The characteristic morphology of Stella spp. cells is that of a flat, six-pointed star (Star of David). There are also intermediate forms which resemble either flat prosthecobacteria, such as the flat triangles observed in organisms assigned to the genus "Labrys" (15) or the genus "Angulomicrobium" (14), or the square-shaped halophile described by Walsby (16).

The methods of reproduction of the star-shaped bacteria are quite similar in all of the strains examined so far; cell division proceeds by cross-wall formation along a line where the cell has the smallest diameter and between opposite pairs of prongs. Both daughter cells retain three prongs each from the mother cell and then form three new prongs (10). Ultrastructural analysis revealed a typical gram-negative cell envelope, except for the characteristic outermost layer formed by polygonal prong structures situated outside the outer membrane (10). The cytoplasm appears to be similar to that of other gram-negative bacteria, and so far no obvious membrane component has been observed that might account for the prong structures that occur on the flat cells. Poly- $\beta$ - 
TABLE 1. Strains of Stella spp. used in this study

\begin{tabular}{|c|c|c|c|}
\hline Strain & Origin & $\begin{array}{l}\text { Gas } \\
\text { vesicles }\end{array}$ & $\begin{array}{l}\mathrm{G}+\mathrm{C} \\
\text { content } \\
(\mathrm{mol} \%)\end{array}$ \\
\hline AUCM B- $1137^{\mathrm{T}}$ & $\begin{array}{l}\text { Virgin chernozem, } A_{1} \text { layer, } \\
\text { Krassnodar region, USSR }\end{array}$ & - & 72.7 \\
\hline $10 \mathrm{~b}$ & $\begin{array}{l}\text { Garden compost, Cheremet- } \\
\text { jevo, Moscow region }\end{array}$ & - & 72.2 \\
\hline $10 \mathrm{n}$ & $\begin{array}{l}\text { Garden compost, Cheremet- } \\
\text { jevo, Moscow region }\end{array}$ & - & 71.4 \\
\hline $12 b$ & $\begin{array}{l}\text { Cultured soil from Moscow } \\
\text { amended with compost }\end{array}$ & - & 71.4 \\
\hline $12 n$ & $\begin{array}{l}\text { Cultured soil from Moscow } \\
\text { amended with compost }\end{array}$ & - & 72.9 \\
\hline 141 & Horse manure, Moscow & + & 70.0 \\
\hline 142 & Horse manure, Moscow & - & 70.8 \\
\hline 143 & Horse manure, Moscow & + & 71.8 \\
\hline $229^{\mathrm{T}}$ & $\begin{array}{l}\text { Sewage sludge from pig farm, } \\
\text { Leningrad region }\end{array}$ & + & 73.5 \\
\hline 228 & $\begin{array}{l}\text { Sewage sludge from pig farm, } \\
\text { Leningrad region }\end{array}$ & - & 69.3 \\
\hline 15 & $\begin{array}{l}\text { Sediment from the Bay of } \\
\text { Peter the Great near } \\
\text { Vladivostoc, Far East } \\
\text { region }\end{array}$ & - & 70.4 \\
\hline 227 & $\begin{array}{l}\text { 0- to } 1-\mathrm{cm} \text {-layer Takyr with } \\
\text { rice straw amendment, } \\
\text { Kazachstan (final phase of } \\
\text { straw decomposition) }\end{array}$ & - & 70.0 \\
\hline
\end{tabular}

hydroxybutyrate storage granules are apparent within some cells. The morphology of the star-shaped forms can vary with changes in the concentrations of nutrients in the broth, as well as within different strains. For example, strain 228 grown in dilute (1:5) meat-peptone broth consists of asymmetrical cell forms, whereas other strains grown in this medium retain the flat, six-pronged star morphology. Finally, a number of strains in our collection (strains 141, 143, and $229^{\mathrm{T}}$ [ $\mathrm{T}=$ type strain]) contain intracellular gas vesicles (Fig. 1). Since these strains differ in other ways from strains without vesicles in the collection, especially in agar colony appearance, growth rate, etc., I consider the two groups to be distinct species.

Thus, the morphology and mode of reproduction of the star-shaped organisms indicate that they are very distinct from other prosthecobacteria. The major structural features of the organisms in this group and the ability to separate them from other morphotypes of oligotrophic bacteria and from other budding and appendaged bacteria $(2,7,11)$ appear to justify the proposed genus designation made previously (10).

Colony appearance. Colonies of strains AUCM B-1137 ${ }^{\mathrm{T}}$, $15,142,227$, and 228 were grayish white, circular, and compact. After 14 days of incubation at $28^{\circ} \mathrm{C}$ on dilute $(1: 5)$ meat-peptone agar plates, the colonies were approximately $2.5 \mathrm{~mm}$ in diameter. Two strains (strains 10 and 12) of the avacuolate organism produced a number of colonial variants that were sufficiently stable to separate by repeated subcultures. These variants could be segregated into isolates which produced elevated colonies (strains $10 \mathrm{~b}$ and $12 \mathrm{~b}$ ) and isolates which produced flat colonies (strains $10 n$ and $12 n$ ).

In contrast, the strains with gas vesicles (strains 141, 143, and $229^{\mathrm{T}}$ ) produced milky white colonies on medium having the same composition as the medium described above.

Nutrition and growth requirements. A comparative study of the nutrition and growth characteristics of the strains in the collection indicated that they were all able to utilize a variety of organic acids or amino acids as substrates (Table 2). More complex carbohydrate or protein polymers (cellulose, starch, gelatin) were not catabolized. This suggests that the star-shaped bacteria are adapted to substrates released from zones of anaerobic decomposition. However, the growth of all strains in this group was clearly inhibited by high concentrations of these organic compounds.

In addition to the compounds catabolized, the star-shaped bacteria which I examined required $0.01 \%$ yeast extract or Casamino Acids in the growth medium. A mixture containing $0.1 \%$ L-glutamic acid and various B vitamins could substitute for the yeast extract requirement. The star-shaped bacteria are obligately aerobic, and their metabolism is oxidative (13). However, the growth of strains with gas vesicles was inhibited by shaking the broth cultures during incubation, suggesting that they are microaerophilic.

Genome properties. The $\mathrm{G}+\mathrm{C}$ contents of the DNAs of the strains in the collection varied from 69.3 to $73.5 \mathrm{~mol} \%$ (Table 1).

Habitats. The strains of star-shaped prosthecobacteria examined were obtained from a variety of soil, aquatic, and animal fecal materials (Table 1). From ecological observations done by using direct microscopic techniques and enrichment broth cultures, it is apparent that these organisms are found in habitats where active degradation of organic substances is occurring. Thus, these prosthecobacteria are typical representatives of the aerobic oligotrophic microflora of dispersal (17).

From observations reported here and elsewhere $(1,2,7$, 9-13), the cluster of star-shaped bacteria appears to represent a clear and distinct group within the budding and appendaged bacteria. For this reason, I propose that organisms with these features be placed in a new genus, Stella. The mode of cell division (a cross-wall separates two equal daughter cells whose shape is that of two three-pronged crowns) provides a major means for separating the organisms in the genus Stella from other prosthecobacteria in the following genera: Hyphomicrobium, Hyphomonas, Pedomicrobium, Rhodomicrobium, Ancalomicrobium, Ancalochloris, Prosthecomicrobium, and Prothecochloris. The flat cellular morphology of Stella spp. also distinguishes them from organisms in the genus Caulobacter, as well as from the flat triangular cells that multiply by budding, as characterized by organisms in the genus "Labrys"'(15).

A number of variations were observed in several strains of

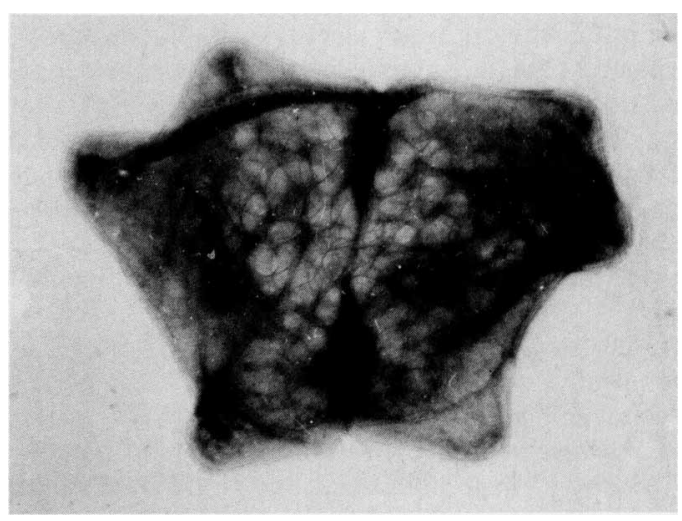

FIG. 1. Cell of Stella vacuolata negatively stained with $1 \%$ uranyl acetate. $\times 18,000$. 
TABLE 2. Utilization of organic acids and amino acids as growth substrates by strains of Stella spp.

\begin{tabular}{|c|c|c|c|c|c|c|c|c|c|c|c|c|}
\hline \multirow[b]{2}{*}{ Carbon source } & \multicolumn{12}{|c|}{ Utilization by strain: $^{a}$} \\
\hline & $\begin{array}{l}\text { AUCM } \\
\text { B-1137 }\end{array}$ & $10 \mathrm{~b}$ & $10 \mathrm{n}$ & $12 b$ & $12 n$ & 141 & 142 & 143 & $229^{\mathrm{T}}$ & 228 & 15 & 227 \\
\hline Pyruvate & + & + & + & + & + & + & + & + & + & + & - & - \\
\hline Lactate & + & - & + & + & + & - & + & + & + & + & + & + \\
\hline Citrate & + & + & + & - & - & + & - & + & + & + & + & + \\
\hline a:-Ketoglutarate & - & - & + & + & + & - & + & + & + & + & + & + \\
\hline Succinate & + & + & + & + & + & + & + & + & + & - & + & + \\
\hline Fumarate & - & - & + & + & + & - & + & + & + & + & - & - \\
\hline Malate & + & - & + & + & + & + & + & + & + & + & + & + \\
\hline Formate & - & - & - & - & - & - & - & - & + & - & - & - \\
\hline Acetate & + & + & + & + & + & + & + & + & + & - & + & - \\
\hline Butyrate & - & - & - & + & + & - & + & - & - & - & - & - \\
\hline Valerate & - & - & - & + & - & - & - & - & - & - & - & - \\
\hline Gluconate & - & - & + & + & + & + & + & + & - & - & - & + \\
\hline L-Glutamic acid & + & + & + & + & + & + & + & + & + & + & - & + \\
\hline L-Aspartic acid & - & - & - & + & + & - & + & + & - & - & - & - \\
\hline L-Asparagine & - & - & + & + & - & - & - & + & + & - & - & - \\
\hline L-Glutamine & - & + & + & + & - & + & + & + & + & - & - & - \\
\hline L-Cysteine & + & - & + & + & + & + & - & + & + & + & - & - \\
\hline L-Cystine & + & + & - & + & + & + & + & + & + & + & - & - \\
\hline L.-Alanine & - & - & + & - & + & + & - & + & + & - & - & - \\
\hline D-Alanine & - & - & - & - & - & - & + & + & + & - & - & - \\
\hline L-Arginine & - & - & - & + & - & - & - & + & - & - & - & - \\
\hline L-Lysine & + & - & + & + & - & + & - & + & - & + & - & - \\
\hline L-Proline & - & - & - & + & - & - & - & + & - & - & - & - \\
\hline DL-Threonine & - & - & - & - & - & + & - & + & - & - & - & - \\
\hline L-Serine & - & - & - & - & - & + & - & - & - & - & - & - \\
\hline L-Histidine & - & - & - & + & - & - & - & - & - & - & - & - \\
\hline
\end{tabular}

${ }^{a}+$, Positive; - , negative. All strains were negative for utilization of propionate, benzoate, urea, ethanol, methanol, monomethylamine, DL-leucine, $\mathbf{L}$ isoleucine, DL-methionine, DL-valine, L-tryptophan, L-phenylalanine, L-glycine, L-oxyproline, cellulose, starch, and gelatin.

the newly proposed genus, including aberrant morphology, some variation in cell size, presence or absence of gas vesicles, use of nutrient, and sensitivity to $\mathrm{NaCl}$. During cultivation in the laboratory, some strains of Stella which were initially quite characteristic in their flat, star-shaped appearance also became rather variable in morphology. These variations and aberrations resulted in some difficulty in dividing the members of the genus Stella into clearly distinct species. Thus, the two species designations proposed below are based upon the most obvious differential feature (gas vesicles) that was evident in the organisms examined.

Formal description of Stella gen. nov. Stella (Stel'la. M.L. fem.n. stella star, denoting the star-shaped morphology of the cells) cells are flat, six-pronged stars with radial symmetry in media containing low nutrient concentrations. The cells are gram negative and occur singly or in pairs. Some strains produce gas vesicles. Spores are not formed. Reprocluction is by symmetrical cell division.

Chemoorganotrophic, using a variety of amino acids or organic acids. Aerobic and oxidative. Oligocarbophilic.

Occur in soil, freshwaters, and artificial ecosystems where complete decomposition of organic matter is under way; typically representative of the microflora of dispersal systems.

The $\mathrm{G}+\mathrm{C}$ content of the DNA ranges from 69.3 to 73.5 mol\% (thermal denaturation method).

Type species: Stella humosa

Stella humosa sp. nov. Stella humosa (hu.mo'sa. M.L. fem.adj. humosa from soil, earth) cells are flat, six-pronged stars 0.7 to $3.0 \mu \mathrm{m}$ in diameter in dilute media or in media containing low concentrations of nutrients. The cells occur singly or in pairs. No clusters or aggregates are formed.
Gram negative with typical three-layered cell envelope. Ultrastructure typical of gram-negative bacteria. Nonmotile. Multiplication occurs by symmetrical cell division.

Aerobic. The optimum temperature for growth is 28 to $30^{\circ} \mathrm{C}$.

Chemoorganotrophic. A limited number of organic acids of the tricarboxylic acid cycle and amino acids are utilized as energy sources. Sugars are not utilized. Yeast extract is required by all strains, but may be replaced by glutamic acid and $B$ vitamins in some strains. Polysaccharides and proteins are not degraded. Oligocarbophilic. The optimum $\mathrm{pH}$ range for growth is near neutral for the type strain and slightly alkaline for other strains. Growth of some strains is stimulated by addition of $\mathrm{NaCl}$ (up to a concentration of $1 \%$ ). Catalase and oxidase positive.

Susceptible to neomycin $(0.5$ to $1.0 \mu \mathrm{g} / \mathrm{ml})$; moderately susceptible to penicillin ( $8 \mu \mathrm{g} / \mathrm{ml}$ for the type strain) and monomycin ( 2 to $10 \mu \mathrm{g} / \mathrm{ml}$ for the type strain and strains $10 \mathrm{~b}$, $10 \mathrm{n}, 12 \mathrm{~b}$, and $12 \mathrm{n})$.

Habitat: widely distributed in soils, freshwater sediments, and sewage and sludge, where rapid decomposition of organic matter is under way. Participates in final steps of aerobic decomposition.

The G+C content of the DNA is 69.3 to $72.9 \mathrm{~mol} \%$ (thermal denaturation method). Plasmids so far not detected.

The type strain is strain AUCM B-1137, which has been deposited in the All Union Collection of Microorganisms, Moscow, USSR, and in the Institute of Microbiology, Academy of Sciences, Moscow, USSR.

Stella vacuolata sp. nov. Stella vacuolata (va.cu.o.la'ta. L. adj. vaccus empty, void; L. adj. latus broad, wide; M.L. adj. vacuolata referring to large areas in the cytoplasm which appear empty due to gas vesicle formation) cells are flat, 
six-pronged stars ranging from 1.9 to $2.5 \mu \mathrm{m}$ in diameter and occur singly or in pairs. Clusters or aggregates are not formed. Gram negative; nonmotile. Multiplication by symmetrical division into two three-pronged daughter cells. The distinctive morphological feature is the presence of gas vesicles throughout the cytoplasm. Cells exhibit considerable buoyancy.

Colonies on agar prepared with dilute (1:5) media are milky white, circular, and viscous and may reach $2.5 \mathrm{~mm}$ in diameter.

In liquid broth a pellicle is formed, and sediment occurs in the bottom of the tube. Growth is inhibited by shaking cultures and by $1 \% \mathrm{NaCl}$. The optimum temperature for growth is $28^{\circ} \mathrm{C}$. The optimum $\mathrm{pH}$ for growth is near neutral or slightly alkaline.

Chemoorganotrophic, microaerophilic. Selected amino acids and organic acids of the tricarboxylic acid cycle are utilized as energy sources. There is a growth requirement for yeast extract, although Casamino Acids or L-glutamic acid and a $\mathbf{B}$ vitamin mixture can substitute for yeast extract. Sugars are not utilized but do not inhibit growth. Complex polysaccharides (cellulose, starch) and protein (gelatin) are not utilized.

Habitat: isolated from horse manure and sewage sludge of a piggery.

The $\mathrm{G}+\mathrm{C}$ content of the DNA ranges from 70.0 to 73.5 mol\% (thermal denaturation method). Plasmids not detected.

The type strain is strain 229 , which has been deposited in the culture collection of the Institute of Microbiology, Academy of Sciences, Moscow, USSR.

\section{ACKNOWLEDGMENT}

The improvement in language of the manuscript by two anonymous reviewers is gratefully acknowledged.

\section{LITERATURE CITED}

1. Hirsch, P., M. Muller, and H. Schlesner. 1977. New aquatic budding and prosthecate bacteria and their taxonomic position. Soc. Appl. Bacteriol. Symp. Ser. 6:107-133.

2. Hirsch, P., and H. Schlesner. 1981. The genus Stella, p. 461-465. In M. P. Starr, H. Stolp, H. G. Truper, A. Balows, and H. G.
Schlegel (ed.), The prokaryotes. Springer-Verlag, Berlin.

3. Lysenko, A. M., A. M. Semenov, and L. V. Vasilyeva. 1984. DNA nucleotide composition of prosthecate bacteria with radial cell symmetry. Mikrobiologiya 53:859-861.

4. Nikitin, D. I., L. V. Vasilyeva, and R. A. Lokhmacheva. 1966. New and rare forms of soil microorganisms. Nauka Publishers, Moscow.

5. Skerman, V. B. D., V. McGowan, and P. H. A. Sneath (ed). 1980. Approved lists of bacterial names. Int. J. Syst. Bacteriol. 30:225-420.

6. Staley, J. T. 1968. Prosthecomicrobium and Ancalomicrobium: new freshwater prosthecate bacteria. J. Bacteriol. 95:19211942.

7. Staley, J. T., P. Hirsch, and J. M. Schmidt. 1981. Introduction to the budding and/or appendaged bacteria, p. 451-455. In M. P. Starr, H. Stolp, H. G. Truper, A. Balows, and H. G. Schlegel (ed.), The prokaryotes. Springer-Verlag, Berlin.

8. Terekhova, L. P., A. V. Laiko, R. A. Lokhmacheva, T. N. Lafitskaya, and L. V. Vasilyeva. 1981. The susceptibility of some genera of prosthecobacteria and budding bacteria to antibiotics. Izv. Akad. Nauk SSSR Ser. Biol. 1:143-147.

9. Vasilyeva, L. V. 1970. A star-shaped soil microorganism. Izv. Akad. Nauk SSSR Ser. Biol. 2:308-310.

10. Vasilyeva, L. V. 1972. The peculiarities of ultrastructure and the cycle of development of the bacterium Stella humosa. Izv. Akad. Nauk SSSR Ser. Biol. 5:782-788.

11. Vasilyeva, L. V. 1980 . Morphological grouping of prosthecobacteria. Izv. Akad. Nauk SSSR Ser. Biol. 5:719-737.

12. Vasilyeva, L. V. 1984. Oligotrofic microorganisms as components of biogeocoenosis, p. 232-241. In E. N. Mishustin (ed.), Soil microorganisms as components of biogeocoenosis. Nauka Publishers, Moscow.

13. Vasilyeva, L. V., T. N. Lafitshaya, N. I. Aleksandrushkina, and E. N. Krasilnikova. 1974. Physiologo-biochemical peculiarities of the prosthecobacteria Stella humosa and Prosthecomicrobium sp. Izv. Akad. Nauk SSSR Ser. Biol. 5:699-714.

14. Vasilyeva, L. V., T. N. Lafitskaya, and B. B. Namsaraev. 1979. A new genus of budding bacteria, Angulomicrobium tetraedrale. Mikrobiologiya 46:1033-1039.

15. Vasilyeva, L. V., and A. M. Semenov. 1984. Labrys monahos, a new budding prosthecate bacterium with a radial symmetry. Mikrobiologiya 53:85-92.

16. Walsby, A. E. 1980. A square bacterium. Nature (London) 283:69-71.

17. Zavarzin, G. A. 1970. The notion of microflora of dispersion in the carbon cycle. J. Gen. Biol. Akad. Nauk USSR 31:386-393. 